\title{
Primary Extra-axial Glioblastoma: Case Report and Literature Review
}

\section{Glioblastoma extra-axial primário: relato de caso e revisão da literatura}

\author{
Baraa Dabboucy ${ }^{10}$ Philippe Younes $^{2}$ Abdallah Rahbani ${ }^{3}$ Elie Fahed ${ }^{2}$ Gérard Abadjian ${ }^{4}$ \\ ${ }^{1}$ Department of Neurosurgery, Faculty of Medicine, Lebanese \\ University, Beirut, Lebanon \\ ${ }^{2}$ Department of Neurosurgery, Lebanese Hospital Geitawi, Beirut, \\ Lebanon \\ ${ }^{3}$ Department of Neurology, Epilepsy and Clinical Neurophysiology \\ Unit, Lebanese Hospital Geitawi, Beirut, Lebanon \\ ${ }^{4}$ Departments of Histology and Pathology, Lebanese Hospital \\ Geitawi, Beirut, Lebanon

\begin{abstract}
Address for correspondence Baraa Dabboucy, MD, Beirut 1100,
\end{abstract} \\ Lebanon (e-mail: baraa.dabboucy@gmail.com).
}

Arq Bras Neurocir 2021;40(4):e368-e373.

\begin{abstract}
Keywords

- brain neoplasms

- glioblastoma

- arachnoid

- extra-axial

Glioblastoma multiforme (GBM) is the most frequent and most aggressive primary brain tumor in adults, mainly located in the cerebral hemispheres. In the literature, few cases of primary GBM have been reported to have radiographic and intraoperative features of extra-axial lesions, leading to a diagnostic dilemma. Despite the advances in imaging modalities, the diagnosis of GBM can be challenging, and it is mainly based on the histopathologic confirmation of the excised tumor. We describe the case of a 76year-old previously healthy female patient who presented to our hospital due to speech disturbances and cognitive impairment. The diagnosis of the tumor type on magnetic resonance imaging (MRI) was difficult, as the findings were suggestive of a malignant meningioma due to the heterogeneous enhancement of a dural-based mass with a dural tail sign. Moreover, the intraoperative findings revealed an extra-axial mass attached to the dura. A histological examination confirmed the diagnosis of glioblastoma with arachnoid infiltration. The patient underwent adjuvant radiotherapy and concomitant temozolomide treatment, she had clinical improvement postoperatively, and was stable during the six months of follow-up. Glioblastoma should be considered in the differential diagnosis of primary extra-axial mass with atypical and malignant features, especially in elderly patients.
\end{abstract}

received

December 12, 2020

accepted

February 22, 2021

published online

August 3, 2021
DOI https://doi.org/ 10.1055/s-0041-1730373. ISSN 0103-5355.

\footnotetext{
(c) 2021. Sociedade Brasileira de Neurocirurgia. All rights reserved. This is an open access article published by Thieme under the terms of the Creative Commons Attribution-NonDerivative-NonCommercial-License, permitting copying and reproduction so long as the original work is given appropriate credit. Contents may not be used for commercial purposes, or adapted, remixed, transformed or built upon. (https://creativecommons.org/ licenses/by-nc-nd/4.0/)

Thieme Revinter Publicações Ltda., Rua do Matoso 170, Rio de Janeiro, RJ, CEP 20270-135, Brazil
} 


\section{Abstrata}
Palavras-chave
- neoplasias cerebrais
- glioblastoma
- aracnoide
- extra-axial

O glioblastoma multiforme (GBM) é o tumor cerebral primário mais frequente e agressivo em adultos, localizado principalmente nos hemisférios cerebrais. Na literatura, poucos casos de GBM primário foram relatados com características radiográficas e intraoperatórias de lesões extra-axiais, o que leva a um dilema diagnóstico. Apesar dos avanços nas modalidades de imagiologia, o diagnóstico de GBM pode ser desafiador, e é baseado principalmente na confirmação histopatológica do tumor excisado. Descrevemos o caso de uma paciente do sexo feminino, de 76 anos, previamente hígida, que se apresentou em nosso hospital devido a distúrbios da fala e alterações cognitivas. 0 diagnóstico do tipo de tumor na ressonância magnética foi difícil, pois os achados eram sugestivos de meningioma maligno devido ao realce heterogêneo de uma massa dural com um sinal de cauda dural. Além disso, os achados intraoperatórios revelaram uma massa extra-axial aderida à dura-máter. O exame histológico confirmou o diagnóstico de glioblastoma com infiltração aracnoide. A paciente foi submetida a radioterapia adjuvante e tratamento concomitante com temozolomida, apresentou melhora clínica no pós-operatório, e manteve-se estável durante os seis meses de seguimento. $\mathrm{O}$ glioblastoma deve ser considerado no diagnóstico diferencial de massa extra-axial primária com características atípicas e malignas, especialmente em pacientes idosos.

\section{Introduction}

Glioblastoma multiforme (GBM) is the most common and aggressive primary malignant brain tumor in adults, accounting for $14.6 \%$ of all tumors and $48.3 \%$ of malignant tumors. ${ }^{1}$ It is usually located intra-axially in the deep white matter of the supratentorial region, mainly in the frontal and temporal lobes. ${ }^{2}$ Several neoplastic and nonneoplastic (granulomatous, lymphoproliferative, autoimmune) dural-based entities are reported to clinically and radiographically mimic meningioma. ${ }^{3,4}$ Glioblastoma multiforme with primary extra-axial involvement has rarely been reported in the literature. ${ }^{5}$ Here, we report a case of left temporal GBM with extra-axial features.

\section{Case Report}

A 76-year-old, previously healthy, nonsmoker, and nonalcoholic female patient, presented with verbal paraphasia and attention deficit that had begun in the month prior to her visit. Upon neurological examination, expressive aphasia was noted, and the three-word recall test, along with the backward digit span test, was impaired. There were no other neurological signs, such as focal deficits, motor weakness, cranial nerve deficit, gait instability, or pronator drift. The vital signs and the initial laboratory testing were unremarkable.

A brain magnetic resonance imaging (MRI) scan performed upon admission showed a 5.1-cm left temporal tumor broadly abutting the dural surface at its anterior inferior and medial aspects, with heterogeneous enhancement and surrounded by extensive vasogenic edema. The dura showed a thickened appearance and enhancement (dural tail sign, DTS) surrounding the middle cranial fossa.
A mass effect was produced by the tumor, with compression of the left lateral ventricle and shift of the midline structures to the right by $\sim 3 \mathrm{~mm}$ ( - Fig. 1). The mass also presented a cerebrospinal fluid (CSF) cleft sign (-Fig. 2 ).

A computerized tomography (CT) scan of the chest, abdomen, and pelvis was performed, and failed to reveal a primary tumor. The patient was submitted to appropriate intravenous (IV) hydration, and dexamethasone $8 \mathrm{mg}$ IV every 6 hours to decrease the edema.

The case was discussed in a tumor board meeting, and the main differential diagnoses considered were malignant meningioma and glioblastoma multiforme. The decision was made to proceed with craniotomy to resect the lesion. The patient received standard preoperative medication, including valproate, dexamethasone, cefazolin, and mannitol on the morning of the surgery. Intraoperatively, the tumor was soft, gray, round, extra-axial, and attached to the dura of the left middle cranial fossa inferiorly, and it was indenting but easily resectable from the temporal lobe superiorly and medially. A gross total resection was performed under microscopic magnification.

A postoperative brain MRI showed complete resection of the middle cranial fossa tumor ( - Fig. 3 ). The postoperative course was smooth, and the patient demonstrated progressive clinical improvement in her neurological status. The histopathological result of the specimen was consistent with an isocitrate dehydrogenase 1 (IDH1) mutated glioblastoma with arachnoid infiltration (-Fig. 4). Moreover, there was a glial proliferation of the neoplastic cells within the arachnoid, along with fibrous and angiomatous components, containing necrotic sites, pleomorphism, and a multinucleate and a moderate to marked anisonucleosis with important mitotic activity. The neoplastic cells expressed glial fibrillary 


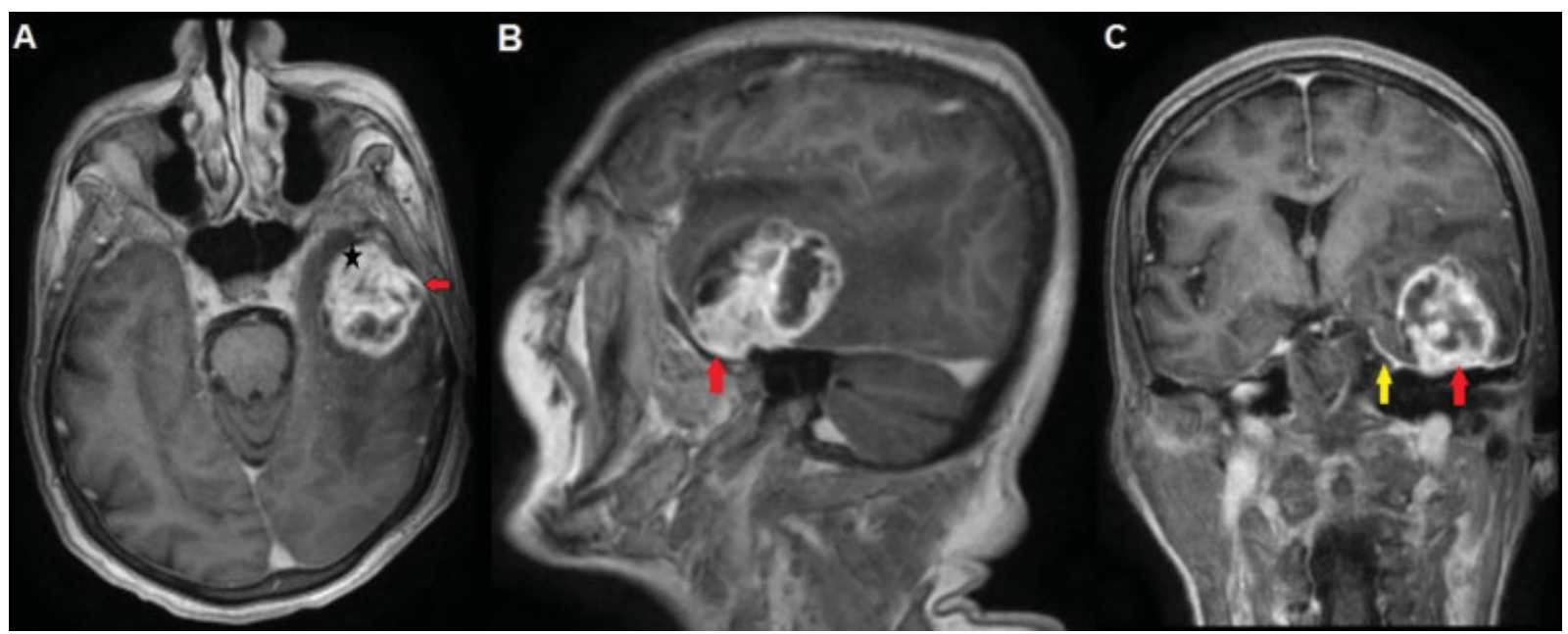

Fig. 1 Axial (A), sagittal (B), and coronal (C) T1-weighted MRI scans with contrast demonstrating a heterogeneously-enhancing mass (asterisk) with broad dural contact anteroinferiorly (red arrow) with a dural tail sign (yellow arrow).

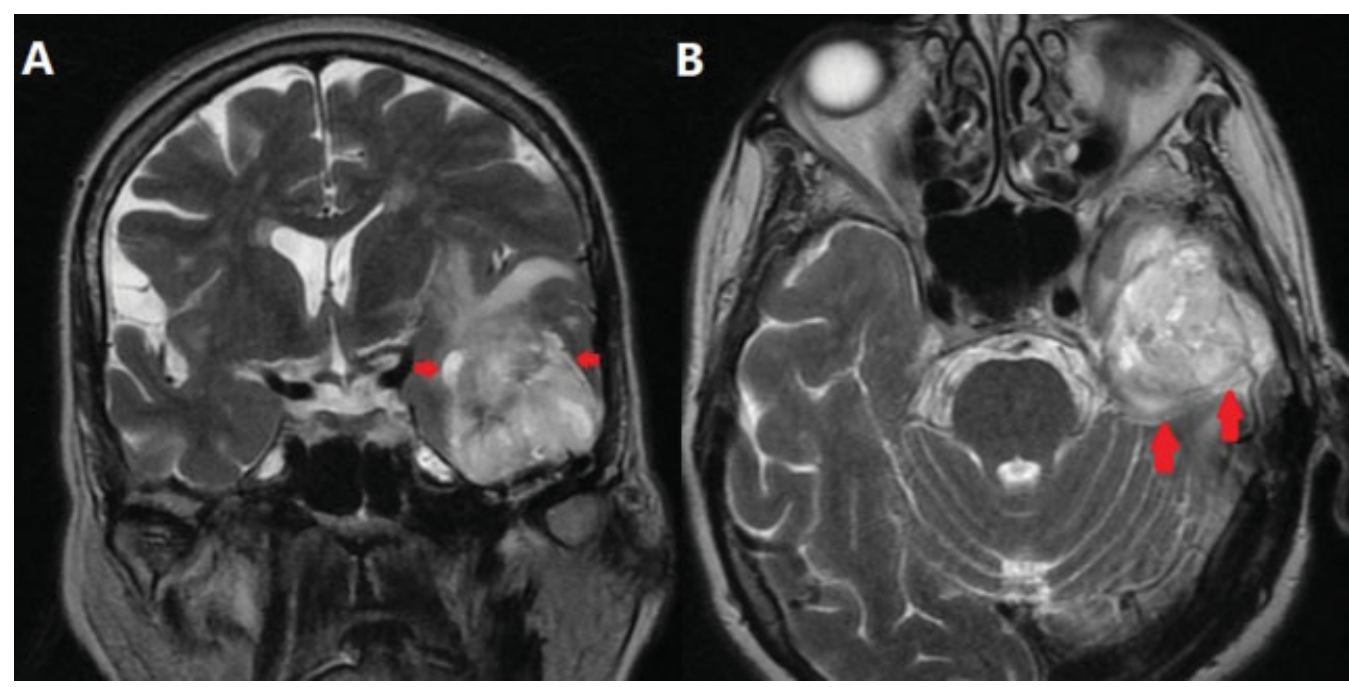

Fig. 2 Coronal (A) and axial (B) T2-weighted MRI scans showing CSF cleft sign (red arrows).

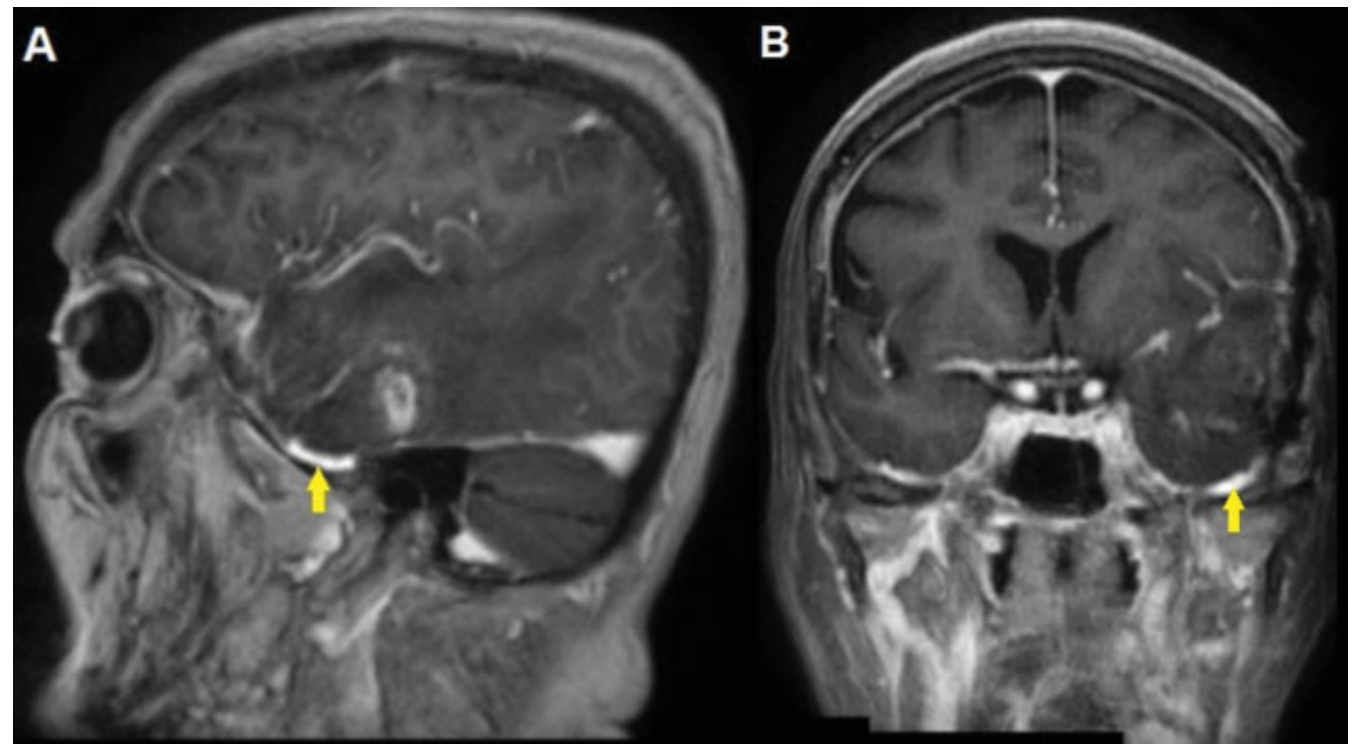

Fig. 3 Sagittal (A) and coronal (B) T1-weighted MRI scans with contrast showing complete surgical resection of the left middle fossa tumor with thickened enhancing dura at the site of dural invasion (yellow arrow). 


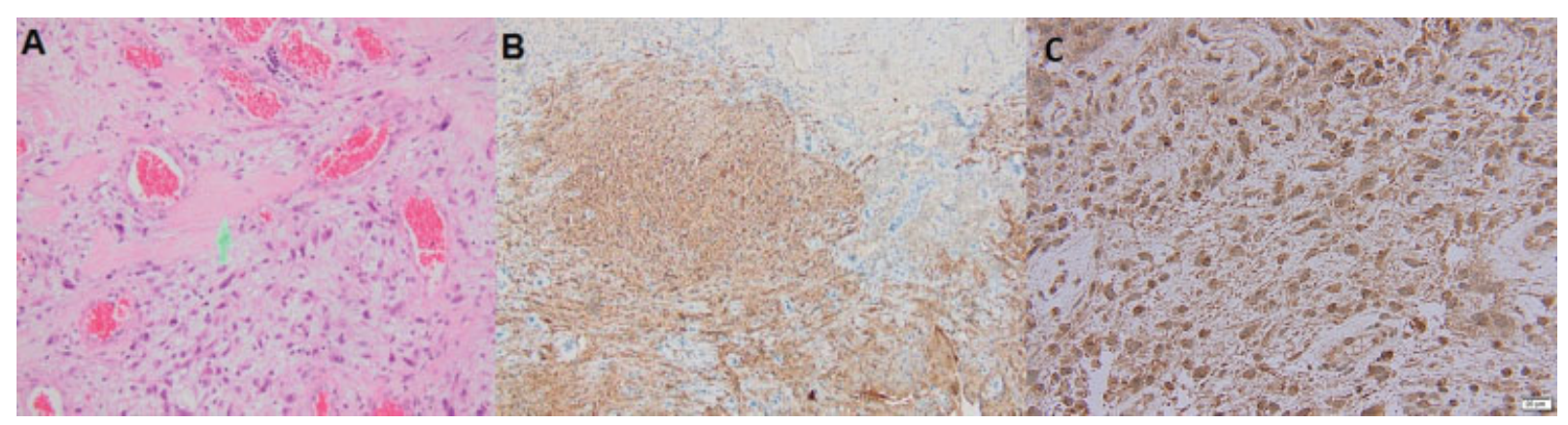

Fig. 4 (A) Fibrous and vascular connective tissue (arachnoid: green arrow) invaded by astrocytes with marked atypia and mitotic figures (hematoxylin and eosin stain, original magnification: X200); (B) cluster of invasive cells positive for GFAP infiltrating the connective tissue (arachnoid) (GFAP immunoperoxidase staining, original magnification: $X 100$ ); (C) immunohistochemical staining reveals strongly positive results for the anti-IDH1 R132H mutation (original magnification: X400).

acidic protein (GFAP), and 30\% were expressing p53. They were positive for S-100 protein and IDH1. The IDH1 mutation was assessed by immunohistochemistry (-Fig. 4).

After the surgery, the patient was treated with radiotherapy and concomitant temozolomide followed by adjuvant temozolomide. The last examination six months after the surgery confirmed that the patient was doing well.

\section{Discussion}

Extra-axial brain tumors, which are responsible for approximately half of all intracranial neoplasms in the United States, include a wide spectrum of pathologic tumors grouped by their primarily extraparenchymal involvement, typically involving the meningeal layers of the brain. ${ }^{6}$ According to the most recent data from The Central Brain Tumor Registry of the United States (CBTRUS, 2012-2016), the most commonly occurring malignant brain tumor was glioblastoma (14.6\% of all tumors), and the most common non-malignant tumor was meningioma (37.6\% of all tumors). ${ }^{1}$ Besides, $1 \%$ to $3 \%$ of meningiomas are classified as malignant meningiomas, which are characterized by higher rates of recurrence, morbidity, and mortality. ${ }^{7}$ Meningioma exhibits a broad-based dural contact, inward displacement of the cortical gray matter, and DTS. ${ }^{8}$

On the other hand, glioblastoma is usually an intra-axial tumor located in the subcortical white matter of the brain hemispheres. ${ }^{9}$ Moreover, GBM can extend to the dura, and rarely shows dural thickening and DTS. ${ }^{10,11}$ The onset of GBMs occurs at a median age of 64 years, but they can occur at any age, including during childhood. Ionizing radiation is one of the few known risk factors to show an increased risk of glioma development. Radiation-induced GBM typically occurs years after therapeutic radiation for another tumor or disease, or due to environmental exposure to vinyl chloride, pesticides, smoking, petroleum refining, and synthetic rubber. ${ }^{12}$ Around $10 \%$ of all GBMs are IDH-mutant, which develop secondarily to progression from a World Health Organization (WHO) grades II or III astrocytoma. ${ }^{13}$ The vast majority of IDH-mutated gliomas occur in persons younger than 55 years of age. In a study cinducted by Robinson and Kleinschmidt-DeMasters, ${ }^{14}$ from a total of 578 gliomas tested for IDH1 mutation, 88 were IDH-mutant gliomas, and only 4 occurred in persons aged 70 or older. The median overall survival in cases of IDH-mutant GBMs carry is significantly better than that of IDH-wildtype GBMs following the standard treatment ( 31 months versus 15 months respectively). ${ }^{15}$ The standard treatment for GBM is surgery, which consists of maximum surgical resection of tumor tissue, even if complete resection is not possible, followed by a course of chemotherapy and/or radiotherapy. Currently, temozolomide, which is approved by the US Food and Drug Administration (FDA), is the preferred chemotherapeutic agent for GBM, and it can be tailored based on the characteristics of the patient. ${ }^{16}$

As therapeutic options remain scarce and prognosis, poor, alternative options such as targeted therapies and immunotherapy are actively examined in clinical trials. Apart from prolonged progression-free, but not overall, survival afforded by the vascular endothelial growth factor antibody, bevacizumab, no pharmacological intervention has been demonstrated to change the course of the disease. ${ }^{17-19}$

The classic imaging feature of GBM is a ring-enhancing intra-axial lesion on MRI or CT; however, peripheral lesions rarely present dural thickening and DTS. ${ }^{9-11}$ "Dural thickening", "DTS", "flare sign," and "meningeal sign" are synonyms referring to the thickening of the dura adjacent to an intracranial neoplasm on contrast-enhanced T1-weighted MRI scans. Originally thought to be pathognomonic for meningioma, DTS was reported in CNS lymphoma, metastasis, multiple myeloma, GBM, chordoma, schwannoma, pleomorphic xanthoastrocytoma, hemangiopericytoma, medulloblastoma, eosinophilic granuloma, and pituitary adenoma. ${ }^{11}$ Additionally, gliosarcoma, which accounts for $1 \%$ to $8 \%$ of glioblastomas and demonstrates both glial and sarcomatous differentiation, when it's located peripherally in the brain, may simulate meningioma by having DTS and homogenous enhancement. ${ }^{20}$ The CSF cleft sign, which is defined as a thin rim of CSF between the tumor body and the brain parenchyma, may be more advantageous in differentiating intracranial extra-axial tumors from intra-axial tumors. ${ }^{21}$ However, malignant or grade-III meningioma may lack the CSF cleft sign or clear demarcation between the tumor and the brain parenchyma. ${ }^{22}$

In the literature, there is limited data regarding the diagnostic confusion between malignant meningioma and GBM, and primary extra-axial involvement of GBM is rarely 
Table 1 Major characteristics of primary extra-axial GBM case reports

\begin{tabular}{|c|c|c|c|c|c|}
\hline Authors, year & $\begin{array}{l}\text { Sex/Age } \\
\text { (years) }\end{array}$ & Location & $\begin{array}{l}\text { Duration } \\
\text { of symptoms }\end{array}$ & Treatment & Prognosis \\
\hline Derrig et al., ${ }^{24} 1986$ & Female/62 & $\begin{array}{l}\text { Base of right mid- } \\
\text { dle cranial fossa }\end{array}$ & 6 weeks & $\begin{array}{l}\text { Resection, neon heavy- } \\
\text { particle radiation }\end{array}$ & Dead after 6 months \\
\hline Gheyi et al., ${ }^{23} 2004$ & Male/68 & $\begin{array}{l}\text { Right frontoparie- } \\
\text { tal calvarium }\end{array}$ & Few days & $\begin{array}{l}\text { Near total } \\
\text { resection, EBRT }\end{array}$ & Dead after 143 days \\
\hline Wu et al., ${ }^{26} 2011$ & Male/60 & $\begin{array}{l}\text { Left cerebellopon- } \\
\text { tine angle }\end{array}$ & 2 months & Subtotal resection & Dead after 2 months \\
\hline \multirow[t]{2}{*}{ Patel et al., ${ }^{5} 2016$} & Female/57 & $\begin{array}{l}\text { Right } \\
\text { temporoparietal }\end{array}$ & 1 month & $\begin{array}{l}\text { Resection followed by } \\
\text { concurrent WBRT and } \\
\text { TMZ }\end{array}$ & Not available \\
\hline & Male/60 & Left parasagittal & Not availabel & $\begin{array}{l}\text { Resection followed con- } \\
\text { current WBRT and TMZ } \\
+12 \text { months of adjuvant } \\
\text { TMZ }\end{array}$ & $\begin{array}{l}\text { Dead after } \\
28 \text { months }\end{array}$ \\
\hline Lee et al., ${ }^{27} 2017$ & Female/71 & $\begin{array}{l}\text { Left cerebellopon- } \\
\text { tine angle }\end{array}$ & 3 months & $\begin{array}{l}\text { Navigation-assisted SB } \\
\text { followed by conventional } \\
\text { WBRT concurrent with } \\
\text { TMZ }\end{array}$ & $\begin{array}{l}\text { Alive after } 1 \text { year of } \\
\text { the diagnosis }\end{array}$ \\
\hline $\begin{array}{l}\text { Karthigeyan } \\
\text { et al.,28 } 2017\end{array}$ & Female/27 & Left petroclival & 4 months & $\begin{array}{l}\text { Subtotal Resection + Ra- } \\
\text { diotherapy }\end{array}$ & Not available \\
\hline $\begin{array}{l}\text { Taghipour } \\
\text { Zahir et al., } 252018\end{array}$ & Male/60 & $\begin{array}{l}\text { Right frontal } \\
\text { calvarium }\end{array}$ & 1 year & $\begin{array}{l}\text { Biopsy followed by WBRT } \\
\text { and concomitant TMZ + } \\
\text { adjuvant TMZ }\end{array}$ & Dead after 7 months \\
\hline Present case report & Female/76 & Left temporal & 1 month & $\begin{array}{l}\text { GTR followed by WBRT } \\
\text { and concomitant TMZ + } \\
\text { adjuvant TMZ }\end{array}$ & Alive after 6 months \\
\hline
\end{tabular}

*Abbreviations: EBRT, external-beam radiation therapy; GBM, gliobastoma multiforme; GTR, gross total resection; TMZ, temozolamide; SB, stereotactic biopsy; WBRT, whole-brain radiation therapy.

reported. Patel et al. ${ }^{5}$ described two cases of glioblastoma mimicking meningioma, with the first case being a heterogeneous-enhancing right temporoparietal mass with broad contact along the right tentorium, CSF cleft sign, and DTS, and the second, a case of a left parasagittal, heterogeneousenhancing mass abutting the falx with DTS. Moreover, Gheyi et al. ${ }^{23}$ reported a case of right frontoparietal mass with both extra- and intra-axial components causing inward displacement of the adjacent dura and calvarial destruction. Derrig at al. $^{24}$ also presented a case of GBM involving the cavernous sinus and Gasserian ganglion with retrograde extension along the trigeminal nerve. Taghipour Zahir et al. ${ }^{25}$ described a case of GBM presenting as a right frontal calvarial mass. Additionally, two cases of primary extra-axial GBM within the cerebellopontine angle were reported by Wu et al. ${ }^{26}$ and Lee et al. ${ }^{27}$ Lastly, Karthigeyan et al. ${ }^{28}$ described a case of extra-axial left petroclival giant-cell GBM. - Table 1 summarizes the major characteristics of the aforementioned cases of primary extra-axial GBM.

The case herein reported reveals that GBM may present as an extra-axial mass based on imaging and intraoperative findings, which render the diagnosis challenging, while the gold standard of diagnosis is still made through surgical pathology. Because of the scarcity of reports of cases of extraaxial GBM in the literature, further studies have to be conducted to define this new entity and whether the prognosis differs from that of intra-axial GBM.

\section{Conclusion}

The present report demonstrates that, although GBM is the most common primary intra-axial malignant brain tumor, it could present as an extra-axial mass with infiltration of the meningeal layers despite the absence of a history of previous trauma, surgery or radiotherapy. Glioblastoma should be considered in the differential diagnosis of extra-axial masses with atypical malignant features, especially in elderly patients.

Conflict of Interests

The authors have no conflict of interests to declare.

\section{References}

1 Ostrom QT, Cioffi G, Gittleman H, et al. CBTRUS Statistical Report: Primary Brain and Other Central Nervous System Tumors Diagnosed in the United States in 2012-2016. Neuro-oncol 2019;21 (Suppl 5):v1-v100

2 Shakur SF, Bit-Ivan E, Watkin WG, Merrell RT, Farhat HI. Multifocal and multicentric glioblastoma with leptomeningeal gliomatosis: a case report and review of the literature. Case Rep Med 2013; 2013:132679 
3 Johnson MD, Powell SZ, Boyer PJ, Weil RJ, Moots PL. Dural lesions mimicking meningiomas. Hum Pathol 2002;33(12):1211-1226

4 Lyndon D, Lansley JA, Evanson J, Krishnan AS. Dural masses: meningiomas and their mimics. Insights Imaging 2019;10(01):11

5 Patel M, Nguyen HS, Doan N, Gelsomino M, Shabani S, Mueller W. Glioblastoma Mimicking Meningioma: Report of 2 Cases. World Neurosurg 2016;95:624.e9-624.e13

6 Dolecek TA, Propp JM, Stroup NE, Kruchko C. CBTRUS statistical report: primary brain and central nervous system tumors diagnosed in the United States in 2005-2009. Neuro-oncol 2012;14 (Suppl 5):v1-v49

7 Willis J, Smith C, Ironside JW, Erridge S, Whittle IR, Everington D. The accuracy of meningioma grading: a 10-year retrospective audit. Neuropathol Appl Neurobiol 2005;31(02):141-149

8 Watts J, Box G, Galvin A, Brotchie P, Trost N, Sutherland T. Magnetic resonance imaging of meningiomas: a pictorial review. Insights Imaging 2014;5(01):113-122

9 Lee KS, Choe G, Nam KH, et al. Immunohistochemical classification of primary and secondary glioblastomas. Korean J Pathol 2013;47(06):541-548

10 Wilms G, Lammens M, Marchal G, et al. Prominent dural enhancement adjacent to nonmeningiomatous malignant lesions on contrast-enhanced MR images. AJNR Am J Neuroradiol 1991;12 (04):761-764

11 Sotoudeh H, Yazdi HR. A review on dural tail sign. World J Radiol 2010;2(05):188-192

12 Davis ME. Glioblastoma: Overview of Disease and Treatment. Clin J Oncol Nurs 2016;20(5, Suppl):S2-S8

13 Ohgaki $\mathrm{H}$, Kleihues P. The definition of primary and secondary glioblastoma. Clin Cancer Res 2013;19(04):764-772

14 Robinson C, Kleinschmidt-DeMasters BK. IDH1-Mutation in Diffuse Gliomas in Persons Age 55 Years and Over.J Neuropathol Exp Neurol 2017;76(02):151-154

15 Yan H, Parsons DW, Jin G, et al. IDH1 and IDH2 mutations in gliomas. N Engl J Med 2009;360(08):765-773

16 Ozdemir-Kaynak E, Qutub AA, Yesil-Celiktas O. Advances in Glioblastoma Multiforme Treatment: New Models for Nanoparticle Therapy. Front Physiol 2018;9:170
17 Paolillo M, Boselli C, Schinelli S. Glioblastoma under Siege: An Overview of Current Therapeutic Strategies. Brain Sci 2018;8(01): 15

18 Le Rhun E, Preusser M, Roth P, et al. Molecular targeted therapy of glioblastoma. Cancer Treat Rev 2019;80:101896

19 McGranahan T, Therkelsen KE, Ahmad S, Nagpal S. Current State of Immunotherapy for Treatment of Glioblastoma. Curr Treat Options Oncol 2019;20(03):24. Doi: 10.1007/s11864-019-0619-4

20 Singh G, Das KK, Sharma P, et al. Cerebral gliosarcoma: Analysis of 16 patients and review of literature. Asian J Neurosurg 2015;10 (03):195-202

21 Kim J, Hong CK, Suh SH, Jung WS, Ahn SJ. The added value of the CSF cleft on ADC in distinguishing extra-axial from intra-axial tumors. Clin Imaging 2017;45:81-85

22 O'Leary S, Adams WM, Parrish RW, Mukonoweshuro W. Atypical imaging appearances of intracranial meningiomas. Clin Radiol 2007;62(01):10-17

23 Gheyi V, Hui FK, Doppenberg EM, Todd W, Broaddus WC. Glioblastoma multiforme causing calvarial destruction: an unusual manifestation revisited. AJNR Am J Neuroradiol 2004;25(09): 1533-1537

24 Derrig P, O'Connor L, Brammer HM, Meriwether M. Glioblastoma multiforme masquerading as a more benign process. AJNR Am J Neuroradiol 1986;7(01):166-167

25 Taghipour Zahir S, Mortaz M, Baghi Yazdi M, Sefidrokh Sharahjin $\mathrm{N}$, Shabani M. Calvarium mass as the first presentation of glioblastoma multiforme: A very rare manifestation of high-grade glioma. Neurochirurgie 2018;64(01):76-78

26 Wu B, Liu W, Zhu H, Feng H, Liu J. Primary glioblastoma of the cerebellopontine angle in adults. J Neurosurg 2011;114(05): 1288-1293

27 Lee JH, Kim JH, Kwon TH. Primary Glioblastoma of the Cerebellopontine Angle: Case Report and Review of the Literature. J Korean Neurosurg Soc 2017;60(03):380-384

28 Karthigeyan M, Ahuja CK, Chatterjee D, Salunke P. Radiologic Dilemma in an Extra-Axial Petroclival Lesion: Low Grade versus High Grade. World Neurosurg 2017;100:713.e1-713.e3 